\title{
AESTHETICS IN IMPLANTOLOGY
}

\author{
Rakesh V. Somanathan, Antonín Šmůnek \\ Charles University in Prague, Faculty of Medicine in Hradec Králové, Czech Republic: Department of Dentistry \\ Summary: Aesthetics in implantology is a topic currently attracting lot of attention from dental implantologists all over the \\ world. It includes both white and red aesthetics with much greater importance been given to the red aesthetics. In this \\ article, both hard tissue and soft tissue procedures and techniques, used in the development of implant recipient sites will \\ be presented and discussed, briefly outlining the treatment planning and also various dental materials used in enhancing \\ aesthetics in implant restorative procedures.
}

Key words: Dental implants; Aesthetics; Grafts; Abutment

\section{Introduction}

Dentistry has evolved over a period in stages from curative to preventive, from preventive to social and from social to community dentistry. From the days of primitive dental sciences there was a quantum leap to the present day practice in the facilities available for diagnosis, treatment and prevention of dental diseases. The recent concepts of implant dentistry is not restricted to the basic needs, but has evolved to cosmetic or aesthetic corrections to uplift the self-esteem and confidence of Man (36). Replacement of missing teeth was a major concern from ancient times and it remained an elusive goal for more than 1500 years. The role of surgical implants in the history of dentistry in replacing missing tooth can be traced to 600 A.D. in Central America where fine dark stones, shaped like tooth were found implanted in some Mayan skulls (35). Brånemark initiated the present surge in the use of implants in 1952 (11,12). Osseointegrated implants have become an integral part of a restorative dentist's armamentarium for helping fully or partially edentulous patients and along with function, aesthetics is also given primary concern (35). Due to high predictability of osseointegration $(1-4,15,25$, $26,30,37,45)$, it may be more important for the restorative dentist to plan and treat individual case with an aesthetic sense and develop criteria that aids in ensuring soft tissue success. Patients have come to expect aesthetically pleasing restorative treatments and now consider a visible crown margin or a poor porcelain/composite color match an unsatisfying treatment outcome. An implantologist has to meet these new challenges, that is, to maintain the optimal red and white esthetics, which are in many instances difficult if not possible to attain.

\section{Treatment planning}

Once a case is diagnosed to be implant compatible one, the next phase is that of treatment planning. It is basically the foremost and most important phase concerned with aesthetics. During treatment planning rechecking the following prerequisites are considered essential: adequate bone volume (horizontal, vertical and contour), optimal implant position (mesiodistal, apicocoronal and buccolingual angulation), stable and healthy periimplant soft tissues, aesthetic soft tissue contours and ideal emergence profile (15). These areas concerning red and white aesthetics should be meticulously planned and treated accordingly to achieve the best aesthetic results without hampering the function.

\section{Optimal implant positioning}

Proper positioning of implant fixture and restoration are important prerequisites for functionally and aesthetically successful implant rehabilitation. This "restorationdriven implant placement" necessitates implant insertion in an optimal 3 dimensional position that relates to final restorative phase of treatment (19).

\section{Mesiodistal position}

Spacing is primarily influenced by periodontal width of adjacent teeth although it fails to consider aesthetically important factors like cervical and coronal width of replaced tooth, presence or absence of diastema and necessity of maintaining the interdental papillae (39). It has now been recommended to keep a distance of $2 \mathrm{~mm}$ between cervical implant face and natural tooth and greater than $3 \mathrm{~mm}$ cervical distance between two implants to minimize the amount 
of crestal bone loss, better soft tissue fill and proper papilla bone support (38). If this distance is compromised there is a greater probability of resorption of interproximal alveolar crest to the level of implants. This loss of interproximal bone results in reduction of papillary height, hampers the emergence profile, and leads to compromised clinical outcomes (13).

\section{Buccolingual position}

Precise planning and construction of the surgical template suggests the proper positioning of implants buccolingually. Spray and colleagues (45), have proposed a critical bone thickness of $1.8 \mathrm{~mm}$ bucolingually to maintain optimum aesthetic outcome. However particularly in the maxillary anterior regions where the implants must be placed with a labial flare this law is sometimes jeopardized concerning the cervical aspect. It creates an unaesthetic screw access opening in the facial aspect of the final screw retained restoration and also a difficulty in achieving proper subgingival emergence profile along with an excessive crown height. Alternatives can be custom castable abutments used to change angulation of the implant $(14,30)$ or to orient implant five degrees palatally and closer to the palatal cortical aspect (1).

\section{Apico-coronal position}

According to Saadoun and colleagues (38), the apicocoronal positioning of implant shoulder is dependent on cervical bone resorption morphology, the diameter of the implant, the size discrepancy between the root and diameter of the implant, the thickness of the marginal gingiva and proximal tissues. They suggest that the implant collar to be located $2 \mathrm{~mm}$ apical to the cementoenamel junction (CEJ) of the adjacent teeth if no gingival recession is present and $3 \mathrm{~mm}$ from free gingival margin when there is, for proper emergence profile maintenance and better aesthetics.

\section{Emergence profile}

The importance of developing a proper emergence profile is critical for achieving a similar appearance for the restoration to that of the adjacent teeth while exiting the soft tissues (15). Development of proper emergence profile begins after second stage surgery, with placement of a properly contoured provisional restoration. This restoration should facilitate ideal gingival scalloping and papilla formation while creating a natural emergence profile to a great extent (47,49-55). Selection of implant also influences the emergence profile considerably (59). Saadoun et al. (39), has put forward specific guidelines for implant fixture diameter when replacing specific natural tooth types for achieving a more ideal emergence profile.

\section{Abutment selection}

Abutments are generally classified into anatomic and non-anatomic abutments. In these the non-anatomic abut- ments are considered to produce less aesthetic results in the form of soft tissue collapse. The choice of abutment types is based on various requirements: visibility, accessibility, tissue architecture, angulation of the implant, interarch distance, tissue height and tissue thickness. Maxillary anteriors face the highest difficulty in abutment selection due to optimal requirement of aesthetics (14). In areas of high visibility with thin buccolingual tissue, especially in maxillary canine area, an abutment that allows porcelain to extent well below the soft tissue should be selected. In areas with uneven soft tissue contours the abutment selected should be a post type abutment that can follow gingival tissue. Due to all these reasons, choosing an abutment is one of the most important factors and so is the most complex task. A preformed abutment is available but still complexity in abutment selection exists. To improve the aesthetics in the maxillary anteriors "Procera abutments" and "Procera allceram" crowns are used now widely (14).

\section{Bone Grafts}

The use of bone graft is an essential tool that is often underused (36). Proper imaging analysis is needed to evaluate the available bone and any bone defects which will hamper the aesthetics directly and function. CT scans disclose bone dimension and the contours of residual ridge and helps in implant positioning $(18,33)$. From these data, recommended specific treatment options based on severity of the defect should be proposed.

\section{Need for a bone graft}

The need for a bone graft is decided only after a thorough evaluation of the local ridge anatomy while considering the goals of the final prosthesis i.e., during diagnostic process (5). The need for bone grafting is too often an isolated decision by the surgeon (37). The important factors to be considered are the ridge height, width and trajectory to the proposed location of the final restoration. Comparable ridge height to adjacent teeth is essential in establishment of natural mucogingival architecture. The adequate width of alveolar ridge is judged as $1.5 \mathrm{~mm}$ bone on both labial and lingual implant surfaces. Leaving a thin labial bone plate at the time of implant placement may lead to periimplantitis or an unaesthetic metal showing through the gingiva (37).

\section{Hard tissue reconstruction}

The volume and contour of the available bone may require augmentation to ensure the stabilization of the implant at stage 1 surgery and to serve as a scaffold for an aesthetically acceptable soft tissue profile (34). To achieve natural aesthetic results, it is necessary to determine whether adequate bone is available for the planned prosthesis (17, 40 ). Once the need for bone graft is established options of regenerative measures must be considered. Bone grafting material can be autografts, xenografts, allografts or alloplasts. Of these, since autografts are transplants taken from 
the same individual, they have no antigenicity of the graft material and are regarded as the "gold standard". Allografts are taken from genetically non-identical individual of same species. The body "converts" the donor bone into host bone $(9,10,31,32)$ and rebuilds the defect. Alloplasts are synthetic, chemically derived bone substitute. Most often alloplasts are formed of calcium phosphate $(23,24)$. Xenografts are transplants from one species to another, most commonly bovine origin.

The choice of the graft material depends on the objective of the surgical procedure. If the objective is to fill an osseous defect then any graft material can be used, but if it is to restore with a living bone $(31,32)$ an osseoinductive material like autograft or freeze dried bone (56-58) must be the choice.

\section{Soft tissue grafting}

Soft tissue grafting procedures have been used successfully for many years in implant surgery in resolving recession defects around natural teeth and augmenting alveolar ridge contours. The concept of optimal biological width around the natural tooth can be applicable to soft tissues around osseointegrated implants also because soft tissues also demonstrate relatively constant dimensions around the implants (13).

\section{Need for soft tissue grafting}

When there is adequate bone and soft tissue present, the restorative dentist can easily modify the soft tissue for these patients by adding or subtracting bulk of abutment (41) or by restoring soft tissue within the subgingival space. But a lack of crestal soft tissue and an intact papillae, advocates the need for soft tissue grafting. The two common situations requiring adjunctive soft tissue procedures are gingival recession around implants and concave ridge profile caused by thin, deficient gingiva (20).

\section{Soft tissue augmentation procedures}

Single implant procedure, particularly in anterior maxilla is aesthetically the most demanding one and so represent an aesthetic challenge to the restorative dentist to provide restorations with normal appearing soft tissue bulk and form. Soft tissue augmentation procedures using patient's masticatory mucosa (palate) have been routinely performed, to create a new zone of attached keratinized gingiva $(44,46)$. But these procedures faced aesthetic adversities in the form of inconsistency in colour and thickness of donor tissue. Currently depending on the cause of recession, various surgical procedures such as, double split papillae (15), lateral sliding pedicle flaps (22) and coronally repositioned flaps $(7,28)$ are used. Soft tissue augmentation procedures are used when a concave rather than a convex profile of gingiva at the implant site is spotted after the resolution of swelling, following implant placement (21). The patient can have sufficient bone volume.
These adjunctive procedures can be performed at healing period or at the time of implant exposure $(8,29,48)$.

(1) Procedures performed at healing period:

Subepithelial connective tissue grafts $(8,29)$ are performed during the healing period. It is done approximately 2 months after placement of implants. The graft is harvested from the palate.

(2) Procedures performed at implant exposure:

Deepithelialized connective tissue pedicle graft or palatal roll (48) technique is used for soft tissue augmentation in the healing period. It is regarded as a simple and predictable technique.

\section{Papilla reconstruction:}

Preservation of interdental papillae is essential for an aesthetic single tooth restoration and the retention or reconstruction of the same should be considered in the design of the flap at the stage 1 surgery itself. The height of the papilla depends on the height of the underlying crestal bone on the adjacent teeth $(19,41)$. Probability of achieving adequate papillae decreases when the distance of crestal bone level of adjacent teeth to the proposed contact of the restoration increases $(6,20)$.

According to Tarnow and colleagues (49), optimal conditions exist when the distance between the interproximal bone crest and the apical level at the proximal surfaces is less than $5 \mathrm{~mm}$. If this distance exceeds $5 \mathrm{~mm}$, interproximal bone may be raised by Guided Bone Regeneration (GBR) (43) or by orthodontic forced eruption (22). Soft tissue augmentation procedures using epithelial-connective tissue graft (27), interpositional connective tissue graft (27), roll technique (42), double papillae repositioned flap (16) etc. can be used for papillary reconstruction. Position and angulations of implant also influence the growth of interdental papilla. Three factors that influence papilla growth (53) are:

(a) lateral pressure exerted by the prosthetic restoration on soft tissues in the interproximal zone.

(b) emergence profile of the provisional restoration.

(c) establishing a vertical proximal surface of contact close to gingival embrasure, with its apical limits located less than $5 \mathrm{~mm}$ from osseous crest.

\section{Conclusion}

Having reasonably perfected the choice of implant and abutment the present attempt by the implantologist is to attain perfection in aesthetics especially red or soft tissue aesthetics. The aim is to achieve a naturally looking and aesthetically appealing gingiva and associated structures. We have come a long way from the primitive dentures and implants. But the quest for perfection is never ending. This review covers an overall picture about the aesthetic considerations of importance while a dental implant surgery is contemplated. 


\section{References}

1. Adell R, Eriksson B, Lekholm U, Brånemark PI, Jemt T. Long term follow up study of osseointegrated implants in the treatment of totally edentulous jaws. Int J Oral Maxillofac Implants 1990;5:347-59

2. Albreksson T, Lekholm U. Osseointegration. Current state of art. Dent Clin N Amer 1989;33:537-42.

3. Albreksson T, Jansson T, Lekholm U. Osseointegrated dental implants. Dent Clin N Amer 1986;30:151-65.

4. Albreksson T, Zarb G, Worthington P, et al. The long-term efficiency of currently used dental implants: A review and proposed criteria of success. Int $\mathbf{J}$ Oral Maxillofac Implants 1986;1:11-7.

5. Bahat O, Daftary F. Surgical reconstruction. A prerequisite for long term implant success. A philosophic approach. Pract Periodontics Aesthet Dent 1995;9:21-9.

6. Beagle J. Surgical reconstruction of the interdetal papilla: case report. Int J Periodont Rest Dent 1992;12:145-51.

7. Bernimoulin JP, Luscher B, Muhlemann HR. Coronally repositioned periodonta flap. Clinical evaluation after one year. J Clin Periodontol 1975;2:1-8.

8. Block MS. Deepithelialized connective tissue pedical graft, the palatal roll. Atlas of the Oral Maxillofac Surg Clin N Amer 1999;7:109-15

9. Bowers G, Chanroff B, Carnevale R et al. Histologic evaluation of new attachment apparatus formation in humans. Part II. J Periodontol 1989;60:675-82.

10. Bowers G, Chanroff B, Carnevale R et al. Histologic evaluation of new attach ment apparatus formation in humans. Part III. J Periodontol 1989;60:683-93.

11. Brånemark P-I, Hunnson BO, Adell R, et al. Osseointergated implants in the treatment of edentulous jaw. Scand J Plastic Reconstruct Surg 1977;11,234-7.

12. Brånemark P-I, Zarb GA, Alberktson T. Tissue integrated prosthesis: Osseointegration in clinical dentistry. Chicago: Quintessence Publishing,1985:12-8.

13. Buser D, Martin W, Besler U. Optimizing esthetics for implant restorations in the anterior maxilla. Anatomic and surgical considerations. Int J Oral Maxillofac Implants 2004;19:43-61.

14. Carlos EF, Laércio WV. Metal-free esthetic restorations. Brazil: Quintessence Publishing, 2003:52-68

15. Christopher EK, Misch CE, Khalaf AS, David PS, Wang HL. Implant plastic sur gery; A review and rationale. J Oral Implantol 2004;30:242-53.

16. Cohen DW, Rose SE. The double papillae repositioned flap in periodontal therapy. J Periodontol 1968;39:65-74

17. Daftary F. Natural aesthetics with implant prosthesis. J Aesthetic Dent 1995 $1: 10-9$

18. Duncan JM, Westwood RM. Ridge widening for the thin maxilla: a clinical report. Int J Oral Maxillofac Implants 1997;12:224-32.

19. Garber DA, Belser UC. Restoration driven implant placement with restoration generated site development: Compend Contin Edu Dent 1995;15:796,798, $802-9$.

20. Grunder U. The inlay graft technique to create papillae between implants. J Aesthet Dent 1997;9:165-74.

21. Grunder U, Speilmann HP, Gaderthuel T. Implant supported single tooth replacement in the aesthetic region: a complex challenge. Pract Periodontics Aesthet Dent 1996;8:830-8.

22. Grupe HE: Modified technique for the sliding flap operation. J Periodontol 1966; 37:491-501.

23. Jarcho M. Biomaterial aspect of calcium phosphates. Dent Clin N Amer 1986 30:2547-56

24. Jarcho M. Calcium phosphate as hard tissue prosthetics. Clin Orthop 1981; 157:259-68.

25. Jemt T. Failures and complications in 391 consecutively inserted fixed prosthesi supported by Brånemark implants in edentulous jaws: A study of treatment from the time of prosthesis placement to the first annual check up. Int J Oral Maxillofac Implants 1991:6:270-9.

26. Jemt T, Linden B, Lekholm U. Failures and complications in 127 consecutively placed fixed partial prosthesis supported by Brånemark implants: From prosthetic treatment to first annual check up. Int J Oral Maxillofac Implants 1992:7:40-8.

27. Langer B, Calagna L. The subepithelial connective tissue graft. J Prosthet Dent 1980;44:363-7.

28. Langer B, Langer L. Subepithelial connective tissue graft technique for root coverage. J Periodontol 1985;56:715-20

29. Langer B, Calagna J. The subepithelial connective tissue graft, a new approach to enhancement of anterior cosmetics. Int J Periodot Rest Dent 1982;2:22-8.

30. Leois S, Beumer J, Hornburg W, May P. The UCLA abutment. Int J Ora Maxillofac Implants 1988;3:183-90

31. Mellonig JT, Bowers GM, Cotton W. Comparison of bone graft materials. Part I. New bone formation with autografts and allografts determined by Strontium- 85 . J Periodontol 1981:52:291-6.
32. Mellonig JT, Bowers GM, Cotton W. Comparison of bone graft materials. Part II New bone formation with autografts and allografts determined: a histological evaluation. J Periodontol 1981;52:297-306.

33. Melvyn S.Schwarz, Stephan L, Neil C, Michael R. Computed Tomography in dental implantation surgery. Dent Clin N Amer 1989;33:555-96.

34. Nevins M, Mellonig J. Advantages of local crest augmentation before implant placement. Int J Periodont Rest Dent 1994;2:96-106.

35. Pepas NA, Langer R. New challenges in biomaterials. Science 1994;263:1715-22.

36. Philips K, Kois JC. Aesthetic Peri-implant site development, the restorative connection. Dent Clin N Amer 1998;42:57-67.

37. Rissolo AR, Bennet J. Bone grafting and its essential role in implant dentistry. Dent Clin N Amer 1998;42:91-108.

38. Saadoun AP, Le Gall M. Implant positioning for periodontal, functional and aesthetic results. Pract Periodont Aestht Dent 1992;4:43-53.

39. Saadoun AP, Le Gall M, Touati B. Selection and ideal tri dimensional implant position for soft tissue aesthetics. Pract Periodont Aesthet Dent 1999;11:1063-73.

40. Saadoun AP. Single tooth implant restoration. Surgical management for esthetic results. Int J Dent Symp 1995:3:30-8.

41. Salama H, Salama M, Graber D, Adar P. Developing optimal periimplant papillae within the aesthetic zone. J Aesthet Dent 1995;7:125-33.

42. Scarf D, Tarnow D. Modified roll technique for localized alveolar ridge augmentation. Int J Period Rest Dent 1992;12:415-22.

43. Seibert J. Reconstruction of deformed, partially edentulous ridges, using full thickness onlay grafts. PartI. Technique and wound healing. Compend Contin Edu Dent 1983;5:437-42.

44. Silverstein LH, Leflkove M, Gamick J. The use of free gingival soft tissue to improve the implant/soft tissue interface. J Oral Implantol 1994;20:36-44.

45. Spray JR, Black CG, Moris HF, Ochi S. The influence of bone thickness on facial marginal bone: stage 1 placement through stage II uncovering. Ann Periodontal 2000;5:199-208

46. Sullivan HC, Atkins JH. Free autogenous gingival grafts. I. Principle of successful grafting. Periodontics 1968;6:121-9.

47. Tarnow DP, Chow SC, Wallace SS. The effect of inter implant distance on the height of inter implant bone crest. J Periodontol 2000;71:546-9.

48. Tarnow D, Eskow R. Considerations for single-unit esthetic implant restorations. Compend Contin Educ Dent 1995;16:778-84

49. Tarnow D, Magner AW, Fletcher. The effect of the distance from the contact point to the crest of bone on the presence or absence of interproximal papilla. J Periodontol 1992:63:995-1003

50. Touti B. Custom guided tissue healing for improved aesthetics in implant supported restorations. Int J Dent Symp 1995;3:36-9.

51. Touti B. Double guidance approach for the improvement of the single tooth implant replacement. Dent Implantol Update 1997;8:89-93.

52. Touti B. The double guidance concept. Prac Periodontics Aesthet Dent 1997;9: 1089-94.

53. Touti B. The double guidance concept. Int J Dent Symp 1997;4:4-12.

54. Touti B. Improving aesthetics of implant supported restorations. Pract Periodont Aesthet Den 1995;7:81-92.

56. Urist MR, Strates BS. Bone morphogenic protein. J Dent Res 1971;50 1392-1406.

57. Urist MR, Strates BS. Bone formation in implants of partially and wholly demineralized bone matrix. Clin Orthop 1970;71:271-6.

58. Urist MR, Silverman BF, Buring K et al. The bone induction principle. Clin Orthop 1967;53:243-52.

59. Wohrle PS. The synergy of taper and diameter: enhancing the art and science of implant dentistry with the Replace ${ }^{\mathrm{TM}}$ implant system. Int J Dent Symp 1997; 4:48-52.

Submitted April 2005. Accepted March 2006.

Dr. Rakesh V. Somanathan, BDS, University Hospital, Department of Dentistry, Sokolská 581, 50005 Hradec Králové, Czech Republic. e-mail: rakesh@email.cz 